\title{
Solar Field Optimization and its Impact on Overall Design and Performance of Solar Tower Thermal Power Plant in Bangladesh
}

\author{
Md. Sakib Hossain ${ }^{1, *}$, Soad Shajid ${ }^{2}$ \\ ${ }^{1,2}$ Department of Mechanical and Production Engineering, Islamic University of Technology, Bangladesh
}

\begin{abstract}
Electricity generation using solar thermal power systems can be made more efficient and both technically and economically feasible in countries receiving moderate solar radiation like Bangladesh through thorough optimization of different parts of the power plant. In this paper a theoretical and mathematical framework for optimization of a $150 \mathrm{MW}$ solar tower thermal power plant in Bangladesh which uses molten salt as HTF has been developed by applying different methods of selecting crucial design aspects, such as design point DNI, solar multiple, design point temperature etc. after selecting the most appropriate location based on GHI and DNI data. The effect of these design aspects on the overall design of the power plant including the number of heliostats, solar field land area, tower height, receiver dimensions etc. have also been studied and finally the performance analysis of the power plant has been conducted. Analysis of performance reveals that the optimized power plant would be able to deliver $528.66 \mathrm{GW}$-h electricity annually to the national grid while operating at a capacity factor of $40.2 \%$ and gross-net conversion efficiency of $88.635 \%$. The promising performance of the power plant would encourage further research and innovation regarding large scale electricity generation from solar energy in Bangladesh.
\end{abstract}

\section{Introduction}

Fossil fuels, including coal, oil and natural gas, are currently the world's primary energy source. But Fossilfuel reservoirs are contracting day by day because of the dispensable use of electricity. As an end result, attraction towards renewable energy assets is increasing all around the world. Among all renewable energy resources, solar energy is the most appreciated one as it is boundless and may effortlessly be converted into electrical power[1].Moreover, solar energy is free of cost and nature-friendly. People can harness the sun's energy using two different methods which are solar photovoltaic and concentrated solar power (CSP). CSP technologies utilize focused sunlight to produce energy that can be used to generate electricity. Power produced by CSP technologies are stable, pristine and nature-friendly[2]. Some well known CSP technologies are power tower, parabolic trough collector, linear Fresnel reflector etc. Though brisk advancement took place in the basic structure and market strategies of CSP technologies, capital cost of electricity production seems to be quiet high as power generation is low. So, great endeavors have to be concentrated on research works for increasing the generation of power in developing the CSP technologies[3].

Bangladesh is a country of rivers and one of the largest deltas in the world. In view of her geographical location, she has an extraordinary variation in socioeconomic, topographic and climatic features[4].Owing to Bangladesh's large growth rate over the last 100 years, she turned out to be one of the most crowded countries in the world[5].In 2014 the per capita energy utilization was $311 \mathrm{kwh}$ which is much lower than many other developed countries[6]. In Bangladesh, the aggregate power production is $67.4 \mathrm{TWh}$ according to the Bangladesh Petroleum Statistical Review of World Energy. This demand of energy is generally met by fossil-fuels such as- natural gas, oil, coal etc. Ignition of these fossil-fuels produce about 78.5 metric tons of carbon-di-oxide. Furthermore, $\mathrm{CO}_{2}$ emission is intensifying everyday as energy usage rate is increasing for population growth and fast economic advancement [6-8]. A determined target was set to produce $2470 \mathrm{MW}$ and 3864 MW electricity by 2021 and 2041 respectively from renewable resources according to the final report of power system Master plan 2016 of Bangladesh government [9]. On account of high availability of solar radiation, CSP technology can play an indispensable role to achieve this target and that too without intimidating the nature. At least $3.5 \%$ of GDP of Bangladesh is lost owing to the scarcity of power generation according to a report of Centre for Policy Dialogue (CPD)[10].

\subsection{Why solar energy is appropriate for Bangladesh}

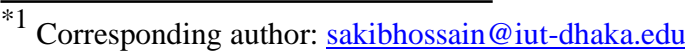


Energy plays a vital role for the advancement of every country. If generation process is favorable, Solar energy can be regarded as the safest source of electricity production out of all other resources. It is believed that sun will last for another 5 billion years and it produces $4 \times 10^{26}$ watts of energy every second [11]. Solar energy is available everywhere; But the largest amount is accessible between $15^{\circ}$ and $35^{\circ}$ latitude north and south. Bangladesh is located between $20^{\circ} 43^{\prime}$ north and $26^{\circ} 38^{\prime}$ south latitude and hence she is in a suitable position for the utilization of solar energy [12]. Bangladesh can achieve socio-economic advantages as well through solar energy. It is highly efficient, much reliable and affordable. In comparison with nuclear energy, it is much cheaper. Greenhouse gas emissions can be reduced by up to $20 \%$ by using solar energy. New technological applications can reduce capital requirement. Electricity can also be supplied to coastal areas by utilizing solar energy. Solar energy does not remain persistent throughout the year in Bangladesh. The average daily solar radiation gained by Bangladesh is about 4-6.5 $\mathrm{KWh} / \mathrm{m}^{2}$.

Any kind of drawbacks of solar energy can be terminated by using modern technologies, aspiration and research. The following figure shows the monthly average solar radiation outline of Bangladesh [13]:

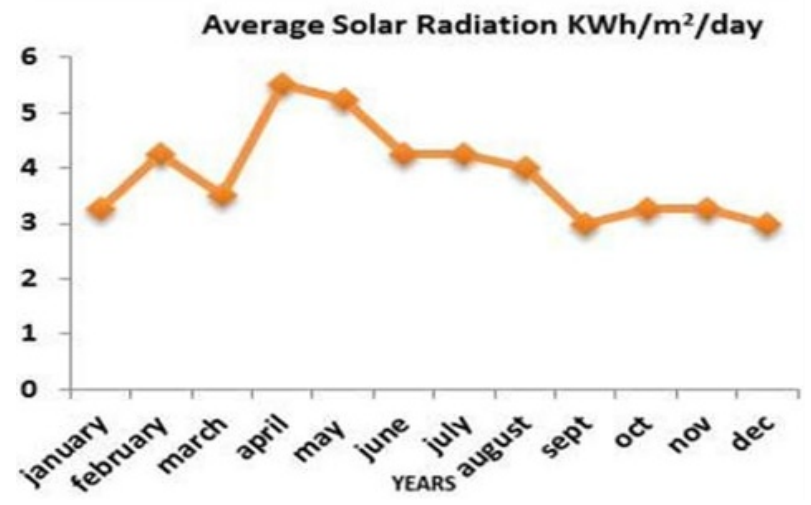

Fig. 1. Annual average Solar Radiation in Bangladesh

\subsection{Concentrated solar power (CSP) technologies:}

Concentrating Solar Power (CSP) plants generate electricity by utilizing reflecting apertures comprised with tracking system to focus the sun rays to a specified location. This will generate heat energy which is used to produce steam that runs a turbine to generate electricity. Large scale generation can be done through this method and it has been in use since 1960's. In modern times, different countries around the world are using this method of power generation as basis to build new power plants. In similar to a conventional thermal power plant, the concentrated sunlight is focused either onto a heat transfer medium or onto high efficiency photovoltaic chips. The turbine coupled with electric power generator is revolved by the produced steam. The sites receiving DNI of around $5.5 \mathrm{kwh} / \mathrm{m}^{2} /$ day are highly befitting for CSP technologies. Presently, the cost of per unit power generation from CSP plants is about 15 to 23 BDT [14]. Solar Tower system is one of the most efficient CSP technologies which is evaluated in this research work in Bangladeshi climatic condition.

\subsection{Solar Tower or Central Receiver System}

This technology makes use of the heliostats which are sun-tracking mirrors. The heliostats can concentrate the solar radiation onto a receiver at the top of the tower. To generate superheated steam for the turbine, a heat transfer fluid is passed through the receiver where it is heated upto $600^{\circ} \mathrm{C}$. In recent times, molten salt is used as the working fluid since it has higher heat transfer rate and energy capabilities than steam. The elevation of the sun in the sky is tracked by heliostat mirrors from east to west for which the tower system has satisfactory winter performance from an optical perspective. As its storage system can eliminate the heat transfer oil, lowering the molten salt requirement and better compatibility with air cooling, it is more efficient [15]. Considering the accumulation of heat from the sun, the solar tower technology and the parabolic trough collector technology can be differentiated.

The pioneer $1 \mathrm{MW}$ solar thermal central receiver system (CRS) in China was modelled and simulated by Yao et al. [16]. By integrating the individual mathematical models of various sub-sections of the CRS using the energy balance approach, they prepared a power plant model. A similar approach was used by Li et al. [17] to coin a thermal model of molten salt cavity receiver. Different criteria such as the surface area of the receiver, incorporated heat loss and tube radius were used for evaluation of the cavity receiver's thermal performance. By developing a basic physical model for solar absorber pipe having solar selective coating, the heat transfer and exergy performance was analyzed and optimized by Lu et al. [18]. However, feasibility of large scale CSP Technology in Bangladeshi or similar climatic condition has been reported in the literature reviews were very few. This work is just an attempt to address the research gap existing in the field of solar tower thermal plants in Bangladesh.

The main objectives of this study are:

- Large power generation by identifying the appropriate design parameters using Solar Tower technologies in a suitable location in Bangladesh.

-To optimise and size the heliostat field and inspect its impact on the overall design and performance of the power plant by simulating it using System Advisor Model (SAM) software.

\section{Method}

The design and optimization criteria of the proposed solar tower power plant in Bangladesh are described in this section. The following sub-sections are formed for the total design:

1. Site Selection

2. Heliostat Field

3. Solar Tower and Receiver Sub section 
4. Power cycle Sub Section

5. Thermal Energy Storage Sub Section

A schematic diagram of the power plant is shown in the figure below:

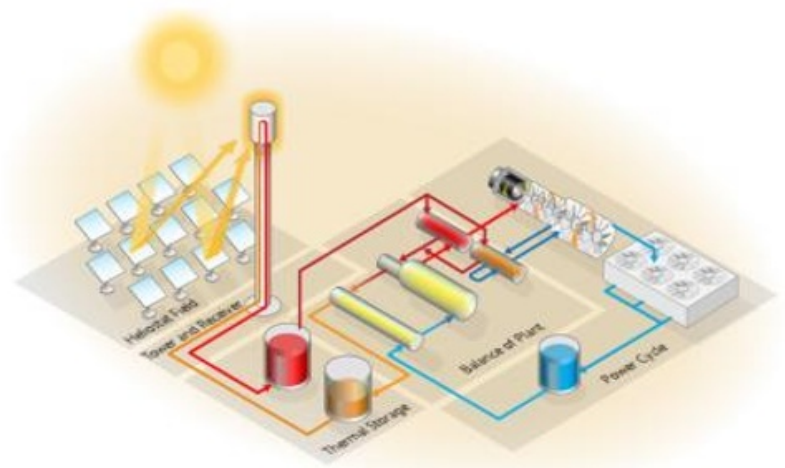

Fig. 2. Schematic Diagram of Solar Tower Power Plant.

The thermodynamic cycle utilized for power generation is the conventional Rankine Cycle. Water is heated by the hot heat transfer fluid coming from the receiver and converts it to super-heated steam. This steam runs the turbine and generates power.

Following figure shows the T-S diagram of Rankine Cycle:

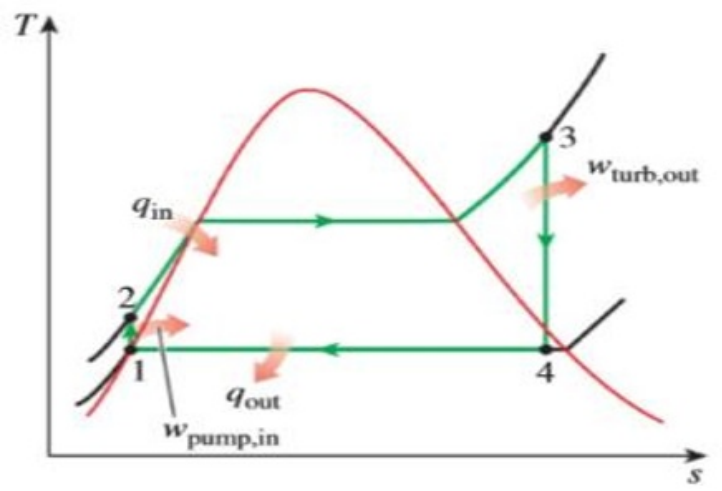

Fig. 3. T-S Diagram of Rankine Cycle

\subsection{Site selection:}

Selection of an appropriate site is the first and foremost challenge for designing a project of such magnitude and it must fulfill all the required measures for its proper functioning. The major aspects to be considered about the location are availability of high and more or less constant solar radiation all around the year, easy access to the location and sufficient water supply for cleaning the mirror panels and other equipment in case of the solar tower based thermal power plant. Keeping these points in mind, numerous potential sites in Bangladesh were explored based on annual Global Horizontal Irradiance (GHI) and Direct Normal Irradiance (DNI) values. These are presented in figure 4-7.

From the above graphs, it can be seen that maximum DNI and GHI values are seen in Cox's Bazar and hence a location beside the river Bakkhali in Cox's Bazar has been selected as the promising site for this study. This location $\left(21^{\circ} 35^{\prime} 0^{\prime \prime} \mathrm{N} 92^{\circ} 01^{\prime} 0^{\prime \prime} \mathrm{E}\right)$ receives $1905 \mathrm{Kwh} / \mathrm{m}^{2}$ DNI annually[12].Moreover, it would provide access to sufficient amount of water being close to the river.

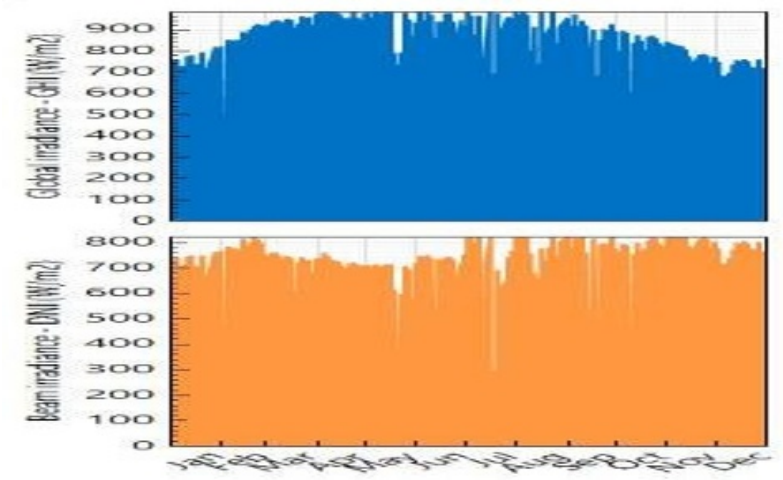

Fig. 4. GHI and DNI of Chittagong

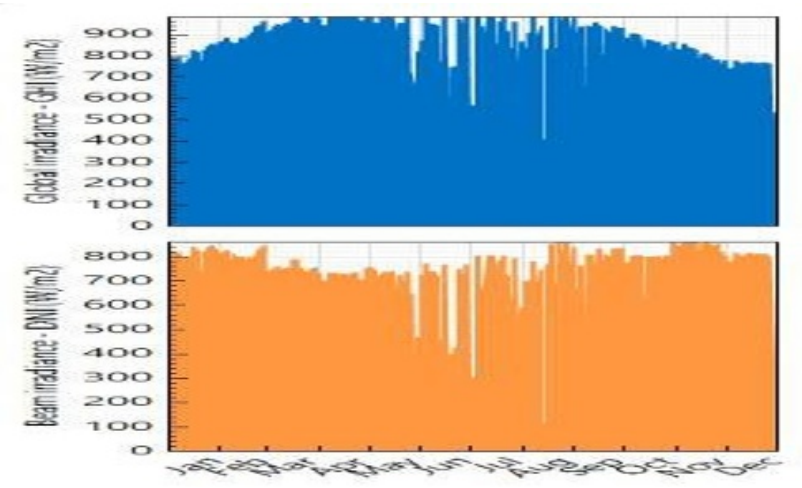

Fig. 5. GHI and DNI of Cox's Bazar

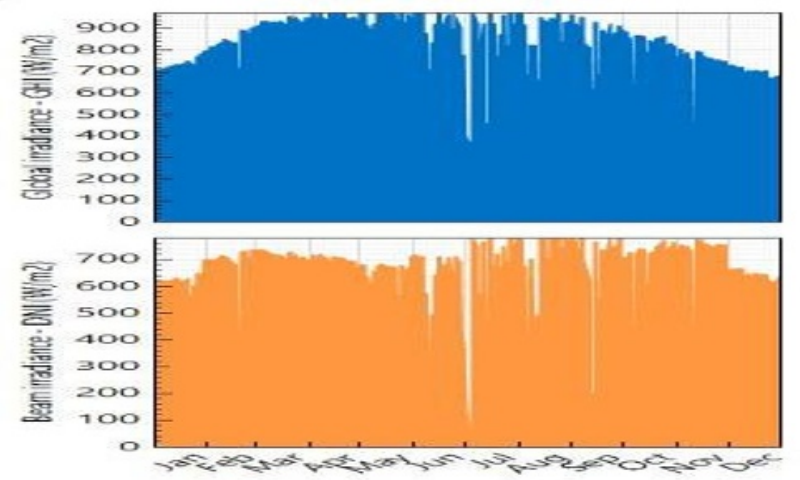

Fig. 6. GHI and DNI in Khulna

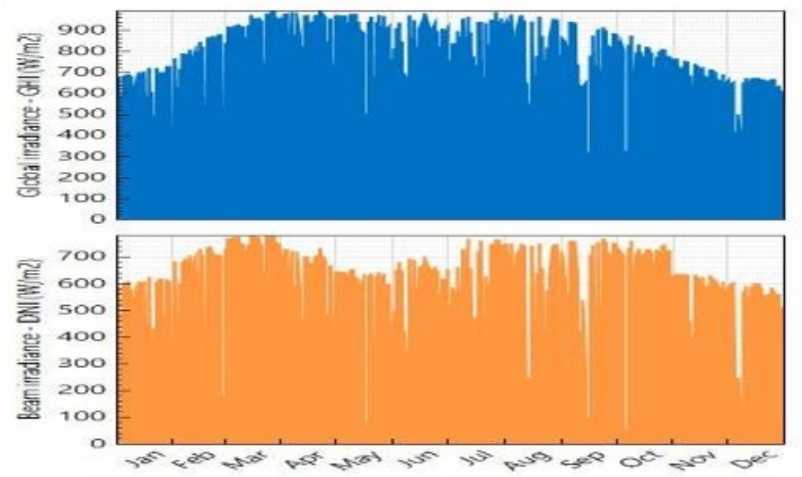

Fig. 7. GHI and DNI in Khulna

\subsection{Solar field design}

The key parameters governing the performance of the solar field are design point DNI, solar multiple (SM), design point temperature etc. Besides these, there are a 
lot of other parameters to be considered while designing the solar field and those are listed in table-1.

\subsubsection{Design Point DNI}

Design point DNI represents the DNI value at which the designed thermal power plant would achieve the desired thermal rating. Increasing the design point DNI implies that lesser number of heliostats are enough to achieve the rated output and vice versa.

\subsubsection{Solar Multiple (SM)}

The parameter solar multiple is the ratio of thermal power generated by the solar field at the chosen design point and the thermal power needed for the power cycle at specified condition. It indicates size of the solar filed with respect to the power generating section in terms of nominal thermal power. Mathematically it can be expressed as:

$$
S M=\frac{\text { Capacity of Solar Field }}{\text { Capacity of Power Cycle }}
$$

\subsubsection{Design Point Temperature}

This is the temperature at which the solar thermal power plant is designed to operate at its full potential. The design point temperature can be selected considering the mean annual temperature of the location or taking the most frequent hourly temperature occurring annually. The heliostats used in this study have square reflecting surface and their specifications are listed in table-1.

Table.1. Specifications of the Heliostats

\begin{tabular}{|l|l|}
\hline Width of Heliostat & $12.2 \mathrm{~m}$ \\
\hline Height of Heliostat & $12.2 \mathrm{~m}$ \\
\hline Heliostat Reflective Area & $144.4 \mathrm{~m}^{2}$ \\
\hline $\begin{array}{l}\text { Reflective Area to Profile } \\
\text { Ratio }\end{array}$ & 0.97 \\
\hline $\begin{array}{l}\text { Total Reflective Area of } \\
\text { Heliostat }\end{array}$ & $1860414 \mathrm{~m}^{2}$ \\
\hline $\begin{array}{l}\text { Image Error (Slope, Single } \\
\text { Axis) }\end{array}$ & $1.53 \mathrm{mrad}$ \\
\hline $\begin{array}{l}\text { Reflected Image Conical } \\
\text { Error }\end{array}$ & $4.32749 \mathrm{mrad}$ \\
\hline $\begin{array}{l}\text { Number of Heliostat Facets } \\
-\mathrm{X}\end{array}$ & 2 \\
\hline $\begin{array}{l}\text { Number of Heliostat Facets } \\
-\mathrm{Y}\end{array}$ & 8 \\
\hline
\end{tabular}

In order to minimize the hindrance caused by the adjacent heliostats, the deploy and stow angles are chosen as $8^{\circ}$. For sun tracking feature each heliostat consumes $0.055 \mathrm{kWe}-\mathrm{hr}$. For protection against high speed wind in stormy condition, the heliostats are designed to stow automatically when the wind velocity exceeds $15 \mathrm{~m} / \mathrm{s}$. Two different losses namely atmospheric attenuation loss and heliostat availability loss contribute to reduce the efficiency of the solar field.
Atmospheric Attenuation Loss: When solar radiation passes through the atmosphere it gets scattered due to collision with dust particles, air molecules and water vapor. As a result, a portion of the reflected radiation from the heliostat changes its direction and cannot reach the receiver.

Heliostat Availability Loss: The heliostat availability loss is defined as the reduction of solar field output caused by soiling, component outages or other events. These two losses are calculated in table-2.

Table. 2.Parameters Related to Various Losses

\begin{tabular}{|l|l|}
\hline \multicolumn{2}{|l|}{ Atmospheric Attenuation } \\
\hline Polynomial Coefficient 0 & 0.006789 \\
\hline Polynomial Coefficient 1 & $0.10461 / \mathrm{km}$ \\
\hline Polynomial Coefficient 2 & $-0.0171 / \mathrm{km}^{2}$ \\
\hline Polynomial Coefficient 3 & $0.0028451 / \mathrm{km}^{3}$ \\
\hline Average Attenuation Loss & $12.8 \%$ \\
\hline Heliostat Availability Losses \\
\hline $\begin{array}{l}\text { Mirror Relfectance and } \\
\text { Soiling }\end{array}$ & 0.9 \\
\hline Heliostat Availability & 0.99 \\
\hline
\end{tabular}

The amount of thermal energy incident on the heliostat field $\left(Q_{s f}\right)$ can be obtained from the following equation:

$$
Q_{s f}=D N I \times A_{h}
$$

Here, $A_{h}$ is the total reflective area of heliostats.

The two losses calculated before along with cosine efficiency, mirror reflectivity, clean error, tracking error, blocking and shading etc. reduces the amount of incident thermal energy focused on to the receiver. The solar field efficiency $\left(\eta_{s f}\right)$ can be readily calculated from the following equation:

$$
\eta_{s f}=\frac{\text { Receiver Thermal Power Incident }\left(Q_{\text {rec }}\right)}{\text { Solar Field Thermal Power Incident }\left(Q_{s f}\right)}
$$

\subsection{Solar tower \& receiver}

On top of the solar tower a receiver is placed where the solar radiation is concentrated and HTF by being passed through it gets heated. For propelling the HTF a pump having $85 \%$ efficiency is used. The designed power plant operates within a temperature range of $290^{\circ} \mathrm{C}-600^{\circ} \mathrm{C}$ i.e. the temperature of the cold fluid entering the receiver is $290^{\circ} \mathrm{C}$, which gets heated to the operating temperature of $600^{\circ} \mathrm{C}$. In total the receiver consists of 20 panels. The parameters to be optimized while designing tower and receiver depending on the solar field are tower height, receiver height and receiver diameter. Besides these, other arbitrary design parameters related to the tower and receiver dimension and heat transfer properties are presented in table-3.

Table. 3. Tower and Receiver Properties

\begin{tabular}{|l|l|}
\hline $\begin{array}{l}\text { Outer Diameter of Receiver } \\
\text { Tube }\end{array}$ & $40 \mathrm{~mm}$ \\
\hline Thickness of Tube Wall & $1.25 \mathrm{~mm}$ \\
\hline
\end{tabular}




\begin{tabular}{|l|l|}
\hline Coating Emittance & 0.88 \\
\hline Coating Absorptance & 0.94 \\
\hline Heat Loss Factor Receiver & 1 \\
\hline $\begin{array}{l}\text { Maximum Delay } \\
\text { Operation Fraction }\end{array}$ & 0.25 \\
\hline $\begin{array}{l}\text { Receiver Startup Dergy Fraction } \\
\text { Energe Del }\end{array}$ & 0.25 \\
\hline
\end{tabular}

The receiver is made from Stainless AISI316 as it has excellent heat resistant capacity. The maximum heat flux incident on the receiver and accompanying loss of heat depends on the material type, HTF, flow velocity of HTF and the coefficients of heat loss. Heat loss also occurs when the HTF flows through the piping system and this has also been incorporated in the study. The parameters controlling the receiver flux and piping loss are shown in table-4.

Table. 4. Receiver Flux and Piping Loss Parameters

\begin{tabular}{|l|l|}
\hline Maximum Receiver Flux & $1000 \mathrm{kWt} / \mathrm{m}^{2}$ \\
\hline $\begin{array}{l}\text { Estimated Heat Loss from } \\
\text { the Receiver }\end{array}$ & $30 \mathrm{kWt} / \mathrm{m}^{2}$ \\
\hline $\begin{array}{l}\text { Receiver Flux Map } \\
\text { Resolution }\end{array}$ & 20 \\
\hline $\begin{array}{l}\text { Number of Days in Flux } \\
\text { Map Lookup }\end{array}$ & 8 \\
\hline $\begin{array}{l}\text { Hourly Frequency in Flux } \\
\text { Map Lookup }\end{array}$ & 2 hours \\
\hline $\begin{array}{l}\text { Piping Heat Loss } \\
\text { Coefficient }\end{array}$ & $10200 \mathrm{Wt} / \mathrm{m}$ \\
\hline Piping Length Constant & 0 \\
\hline Piping Length Multiplier & 2.6 \\
\hline
\end{tabular}

A detailed model used to determine the heat loss occurring in the tower and receiver is shown below [19]: The amount of solar radiation incident on the receiver $\left(Q_{\text {rec }}\right)$ can be calculated from the following equation:

$$
Q_{\text {rec }}=Q_{s f} \times \eta_{s f}
$$

Heat transferred to the HTF, $Q_{\text {BIF }}=Q_{\text {rec }}-Q_{\text {lossopt }}-Q_{\text {lossconv }}-Q_{\text {iessrnad }}$

Where, $Q_{\text {loss,opt }}=$ Optical Loss, $Q_{\text {loss,conv }}=$ Loss of Heat due to Convection and $Q_{\text {loss, } r a d}=$ Heat Loss due to Radiation.

This can also be calculated as follows:

$$
Q_{H T F}=m_{H T F}^{\prime}\left(h_{\text {out }}-h_{\text {in }}\right)
$$

Where, $m_{H T F}^{\prime}=$ Mass Flow Rate of HTF Entering and Leaving the Receiver, $h_{\text {out }}=$ Specific Enthalpy of HTF at Receiver Outlet, $h_{\text {in }}=$ Specific Enthalpy of HTF at Receiver Inlet.

The conduction loss is much less compared to the other losses and hence it is neglected. The optical loss can be calculated as:

$$
Q_{\text {loss }, o p t}=Q_{r e c} \times\left(1-\eta_{\text {opt }}\right)
$$

Where, $\eta_{\text {opt }}=$ Optical Efficiency of the Receiver
Finally, the efficiency of the receiver $\left(\eta_{\text {rec }}\right)$ can be calculated from the following equation:

$$
\eta_{\text {rec }}=\frac{\text { Thermal Power Transferred to } H T F\left(Q_{H T F}\right)}{\text { Receiver Thermal Power Incident }\left(Q_{\text {rec }}\right)}
$$

\subsection{Heat transfer fluid (HTF)}

The main medium of energy carrying and storage is the HTF. An ideal HTF should have the following characteristics:

-High specific heat

-Non-combustible

-High chemical stability

-Low maintenance

- Method of production must have minimum $\mathrm{CO}_{2}$ emission

-Less presence of impurities

Taking these points into consideration, mixture of nitrate salts $\left(60 \% \mathrm{NaNO}_{3}+40 \% \mathrm{KNO}_{3}\right)$ is used as HTF. A temperature range of $260^{\circ} \mathrm{C}$ and $621^{\circ} \mathrm{C}$ is considered for the operation of this mixture of salt. The salt starts to crystalize as the temperature falls and solidifies at $221^{\circ} \mathrm{C}$ [20]. So, even when the power plant is not operating, the temperature of the HTF should be controlled using heating arrangements. Moreover, this HTF shows outstanding performance of corrosion resistance. The average corrosion rate is less than 16.5 microns/year for 13 different alloys in a test conducted for 3000 hours [21]. Density also varies with the change of temperature but for simplification it is considered as constant at $1799.97 \mathrm{~kg} / \mathrm{m}^{3}$.

\subsection{Power cycle and thermal energy storage system (TES)}

A steam turbine coupled with a generator running using conventional Rankine cycle will be operated to convert the thermal energy stored in the HTF to electricity in the power cycle. In the heat exchangers, exchange of thermal energy takes place between hot HTF and water to produce steam. This steam will rotate the turbine coupled with a generator. In absence of solar energy, a thermal energy storage (TES) system can run the power cycle for 6 hours. As a result, power can be generated during night and cloudy conditions. As the peak demand of electricity in Bangladesh mainly occurs after sunset, this storage system is much needed here. The power cycle can produce a gross output of 167MW-e with a gross to net conversion factor of approximately $90 \%$ under suitable operating conditions. The following equations can be used to calculate the efficiency of the heat exchanger system $\left(\eta_{H X}\right)$ and power cycle $\left(\eta_{p c}\right)$ :

$$
\begin{aligned}
\eta_{H X} & =\frac{\text { Power Cycle Thermal Energy Input }\left(Q_{p c}\right)}{\text { Field Thermal Power Incident in HTF }\left(Q_{H T F}\right)} \\
\eta_{p c} & =\frac{\text { Power Cycle Electrical Energy Output }\left(Q_{e}\right)}{\text { Power Cycle Thermal Energy Input }\left(Q_{p c}\right)}
\end{aligned}
$$

The boiler operating pressure of the power block is assumed to be 85 bar and the turbine inlet pressure 
control mode is selected as fixed pressure. For cooling purpose evaporative condenser is used with reference condenser water $\mathrm{dT}$ as $10^{\circ} \mathrm{C}$ and approach temperature as $5^{\circ} \mathrm{C}$.

Direct TES system is considered in this study which means the same HTF is used as storage media. There are two pairs of tanks available for HTF storage. One of the tanks is dedicated for hot HTF and other for cold HTF. The HTF is circulated throughout the system with the help of a pump. To keep the temperature of HTF in cold tank above the operating temperature $\left(290^{\circ} \mathrm{C}\right)$ so that it does not form any precipitation and also to ensure that the temperature of $\mathrm{HTF}$ in hot tank is not below $500^{\circ} \mathrm{C}$, the tanks are equipped with heaters. The heater capacity for the cold and hot tanks are chosen to be $15 \mathrm{MWe}$ and $30 \mathrm{MWe}$ respectively. One of the crucial design aspects in this study is the sizing of the TES system. The following equations can be used to calculate the required storage volume $\left(V_{T E S}\right)$ and thermal capacity $\left(T E S_{c a p}\right)$ of the TES[22]:

$$
\begin{gathered}
V_{T E S}=\frac{c \times 10^{6} \times 3600}{\rho_{H T F} \times C_{H T F} \times \mu_{H X} \times 1000 \times\left(T_{\text {sf }, \text { out }}-T_{\text {st,in }}\right)} \\
T E S_{\text {cap }}=t_{\text {full,load }} \times \frac{W_{\text {des,gross }}}{\eta_{\text {des }}}
\end{gathered}
$$

Here, $C=$ Thermal Capacity, $\rho_{H T F}=$ Density of Heat Transfer Fluid, $\mu_{H X}=$ Heat Index, $T_{s f \text {,out }}=$ Solar Field Output Temperature, $T_{s t, i n}=$ Steam Turbine's Inlet Temperature, $t_{\text {full,load }}=$ number of hours per day the plant operates at full load.

The powerplant can also be operated in parts i.e. during day time heliostat field, receiver and TES systems can be operated to harness and store the solar energy and during peak time the power cycle can be operated using the stored energy. TES $S_{\text {cap }}$ and $V_{T E S}$ are dependent on the solar field parameters.

\section{Results and discussion}

\subsection{Optimization of design point DNI}

The design point DNI can be chosen based on few principles, such as: selecting the mean annual DNI or analyzing the weather data and selecting the most frequent hourly DNI of the location occurring annually. But none of these give optimum result as in both cases the solar field comes out to be over designed. In this study the design point DNI is selected to be equal to the $90 \%$ value of the PDF/CDF data of annual DNI of Cox's Bazar. For solar tower thermal power plant choosing the design point DNI based on this criterion gives the best result[23].

From fig- 8 it is seen that $90 \%$ of PDF and CDF value of the site comes out to be $775 \mathrm{~W} / \mathrm{m}^{2}$. The solar field has been designed considering this value as the design point DNI.

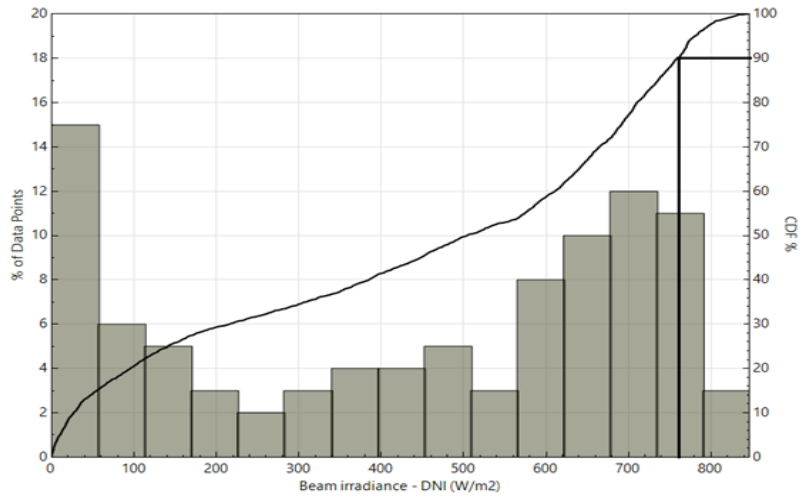

Fig. 8. Design Point DNI Selection

\subsection{Optimization of solar multiple}

Solar multiple is the most critical parameter of solar field design as this directly contributes to the sizing of the field, its efficiency and also the cost. Selecting the optimum value of solar multiple ensures maximum efficiency and minimum cost of electricity generation. An indication of the cost per unit electricity can be obtained from the ratio $\frac{\text { Generated Power }}{\text { Solar Field Land area }}$ as the maximum cost incurred by the power plant is related to the solar field. Maximizing this ratio would result to minimum cost per unit electricity generation. It also ensures maximum efficiency of the solar field and the power plant as a whole since it maximizes energy concentration.

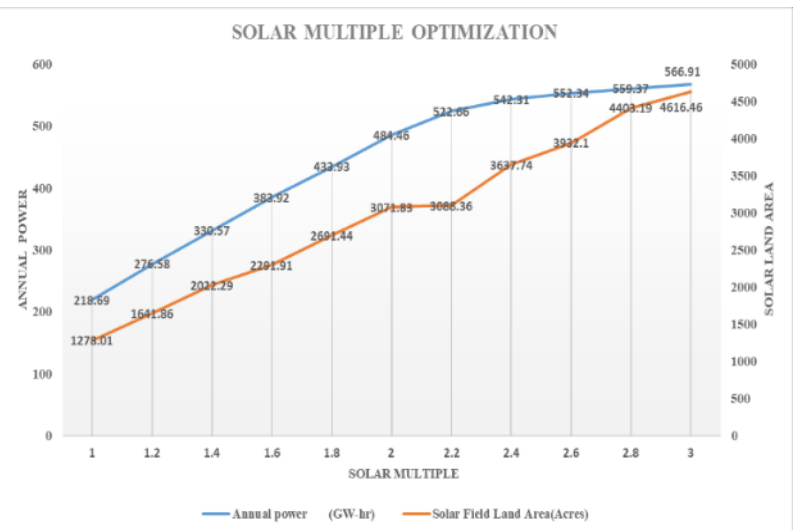

Fig. 9. Solar Multiple Selection

From fig-9 it is evident that at solar multiple 2.2 the ratio $\frac{\text { Generated Power }}{\text { Solar Field Land area }}$ is maximized and hence this has been chosen as the optimum value of SM for Bangladeshi climate. Other important parameters governing the performance of the power plant which are directly influenced by solar multiple are number of heliostats, height of the solar tower, dimensions of the receiver, receiver thermal power, maximum flow rate to the receiver, cycle thermal power, cycle design HTF mass flow rate, sizing of the TES system and the solar field design as a whole.

\subsubsection{Solar multiple and number of heliostats}

As the value of solar multiple increases the number of heliostats required increases almost linearly. Between 
SM value 2-2.2 the slope of the line slightly decreases (fig-10) and hence this validates the selection of SM value as 2.2 to be the optimum one. At 2.2 SM, 15008 heliostats are required for the design considerations to be implemented. With the increase of SM, solar field becomes denser and the overall area occupied by the field increases too. At the same time, the distribution of the heliostats becomes more even (SM 2.8). These effects are shown in figure 11-14.

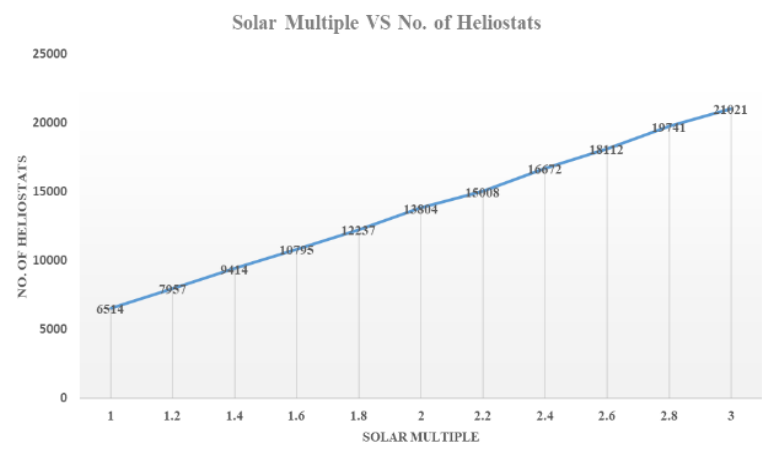

Fig. 10. Relation between Solar Multiple and Number of Heliostats

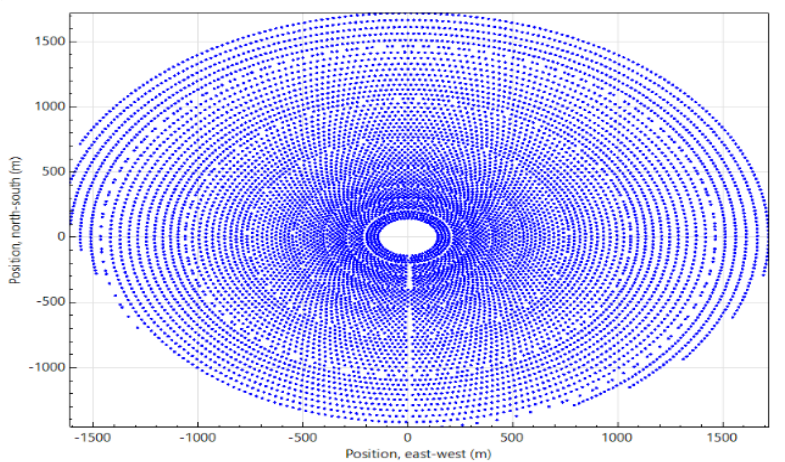

Fig. 11. Solar Field Design for SM 1.4

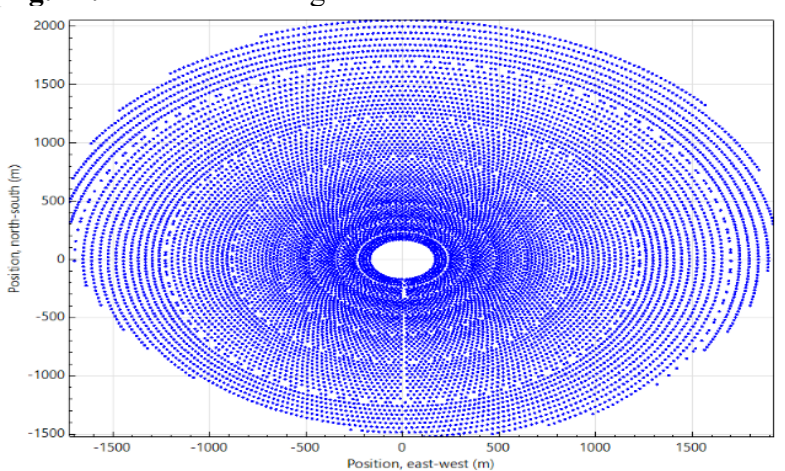

Fig. 12. Solar Field Design for SM 1.8

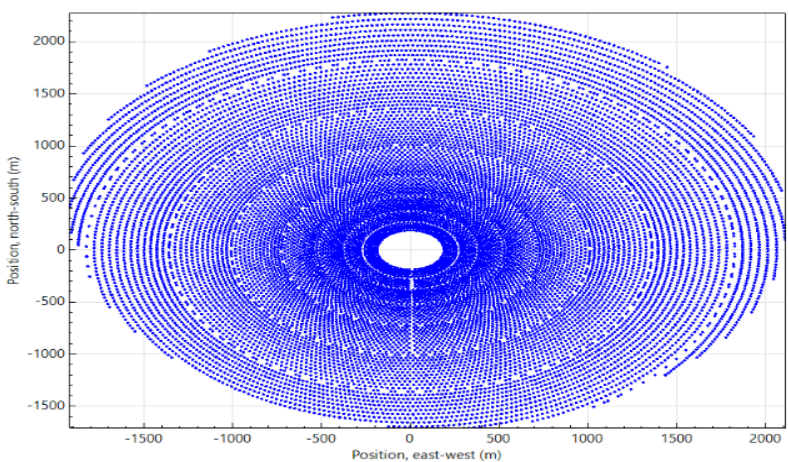

Fig. 13. Solar Field Design for SM 2.2 (Optimum)

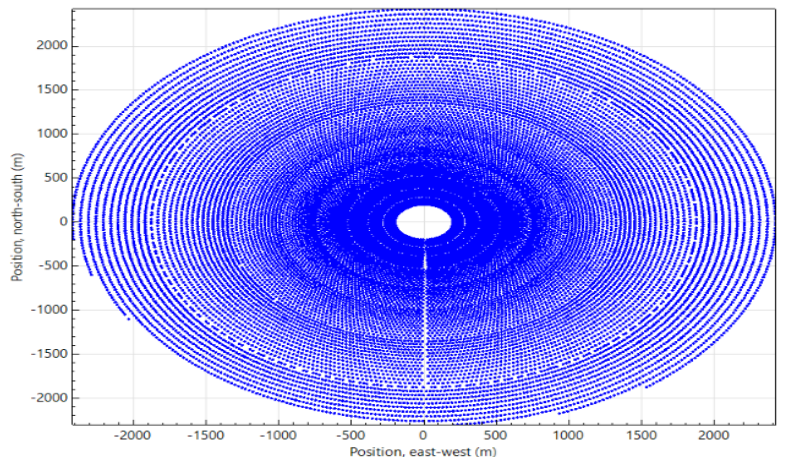

Fig. 14. Solar Field Design for SM 2.8

\subsubsection{Solar multiple and tower height and receiver dimensions}

The relation between solar multiple and height of the solar tower is not linear. Generally, with the increase of SM the height increases but at SM 2.2, solar tower's height is more than that of SM 2.4. At SM 2.2 the height of solar tower has been calculated as $252.17 \mathrm{~m}$. This trend is shown in fig- 15 .

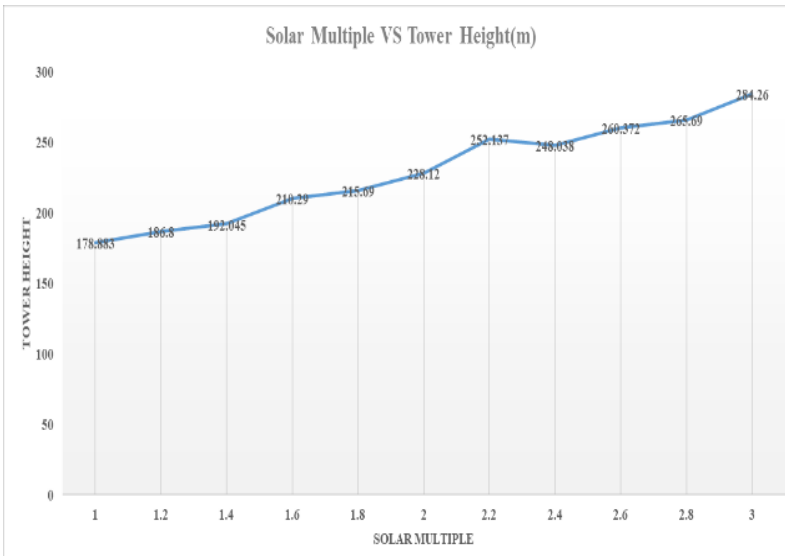

Fig. 15. Relation between Solar Multiple and Tower Height

In case of sizing the receiver, solar multiple plays a vital role. Just like the height of the solar tower, receiver diameter and height also increase with the increase of solar multiple. At SM 2.2 the receiver height and diameter are calculated as $29.83 \mathrm{~m}$ and $19.83 \mathrm{~m}$ respectively. The relation between SM and receiver size is shown in fig-16.

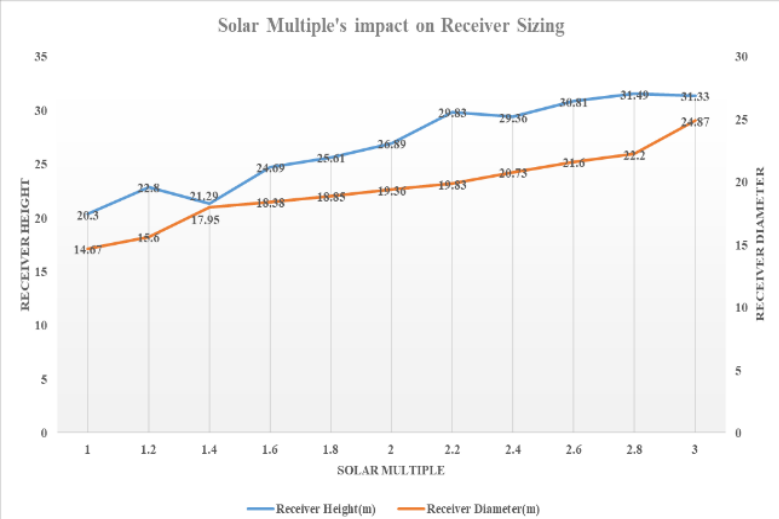

Fig. 16. Solar Multiple's Impact on Receiver Sizing 


\subsection{Optimization of design point temperature}

For choosing the design point temperature two different methods were used. Firstly, the mean temperature calculated from the weather data of NSDRB website, $26.6^{\circ} \mathrm{C}$ was used. Secondly, the most frequent hourly temperature from the weather data of Cox's Bazar (Table-5) was used and in both cases the power plant was simulated for a whole year keeping the other parameters same and it was seen that choosing the later condition gives better power output. Hence, the most frequent hourly temperature which is $28^{\circ} \mathrm{C}$ has been considered in this design.

Table. 5. Selection of Most Frequent Hourly Temperature

\begin{tabular}{|c|c|}
\hline Temperature Range $\left({ }^{\circ} \mathrm{C}\right)$ & Number of Hours \\
\hline $15-17$ & 18 \\
\hline $17.01-19$ & 128 \\
\hline $19.01-21$ & 340 \\
\hline $21.01-23$ & 729 \\
\hline $23.01-25$ & 882 \\
\hline $25.01-27$ & 1660 \\
\hline $\mathbf{2 7 . 0 1 - 2 9}$ & $\mathbf{3 7 2 9}$ \\
\hline $29.01-31$ & 828 \\
\hline $31.01-33$ & 280 \\
\hline $33.01-35$ & 103 \\
\hline $35.01-37$ & 12 \\
\hline $37.01-39$ & 0 \\
\hline
\end{tabular}

\subsection{Performance analysis}

Depending on the optimum values of the design points, the following parameters related to the design of the power plant were calculated (Table-6)

Table. 6. Power Plant Design Parameters

\begin{tabular}{|l|l|}
\hline Receiver Thermal Power & $896 \mathrm{MWt}$ \\
\hline Cycle Thermal Power & $407 \mathrm{MWt}$ \\
\hline Solar Field Land Area & 3088.36 Acres \\
\hline Total Land Area & 3133.36 Acres \\
\hline $\begin{array}{l}\text { Total Heliostat Reflective } \\
\text { Area }\end{array}$ & $2173996 \mathrm{~m}^{2}$ \\
\hline $\begin{array}{l}\text { Maximum Flow Rate to } \\
\text { Receiver }\end{array}$ & $2299.63 \mathrm{~kg} / \mathrm{s}$ \\
\hline Total Piping Length & $629.66 \mathrm{~m}$ \\
\hline Total Piping Loss & $6422.53 \mathrm{KWt}$ \\
\hline $\begin{array}{l}\text { Cycle Design HTF Mass } \\
\text { Flow Rate }\end{array}$ & $871.1 \mathrm{~kg} / \mathrm{s}$ \\
\hline TES Thermal Capacity & $2443.9 \mathrm{MWt}-\mathrm{hr}$ \\
\hline Storage Tank Volume & $11003 \mathrm{~m}^{3}$ \\
\hline $\begin{array}{l}\text { Available HTF Volume in } \\
\text { TES }\end{array}$ & $10453 \mathrm{~m}^{3}$ \\
\hline $\begin{array}{l}\text { Estimated Heat Loss from } \\
\text { TES }\end{array}$ & $0.62 \mathrm{MWt}$ \\
\hline
\end{tabular}

On simulation for a whole year using SAM software, it was seen that the optimized power plant would be able to supply $528.66 \mathrm{GW}-\mathrm{hr}$ electricity annually to the national grid operating at a capacity utilization factor (CUF) of 40.2. The CUF of the power plant is quite encouraging since grid connected solar thermal power plants worldwide on average operates at only $18 \%$. [2426]. The gross to net conversion efficiency of the power plant came out to be $88.635 \%$. Annually $1791748 \mathrm{~m}^{3}$ water would be required, mainly for operation and maintenance and facilitating evaporative cooling. The amount of power generated from the power plant varies from month to month since DNI doesn't remain constant all throughout the year. The monthly power generation is shown in fig-17. It is seen that the maximum power is generated in the month of January (58.76 GW-hr) and minimum in the month of July (19.33 GW-hr). On average $53.77 \mathrm{~kg} / \mathrm{s}$ water has to be supplied to the power cycle for makeup and cooling purpose.

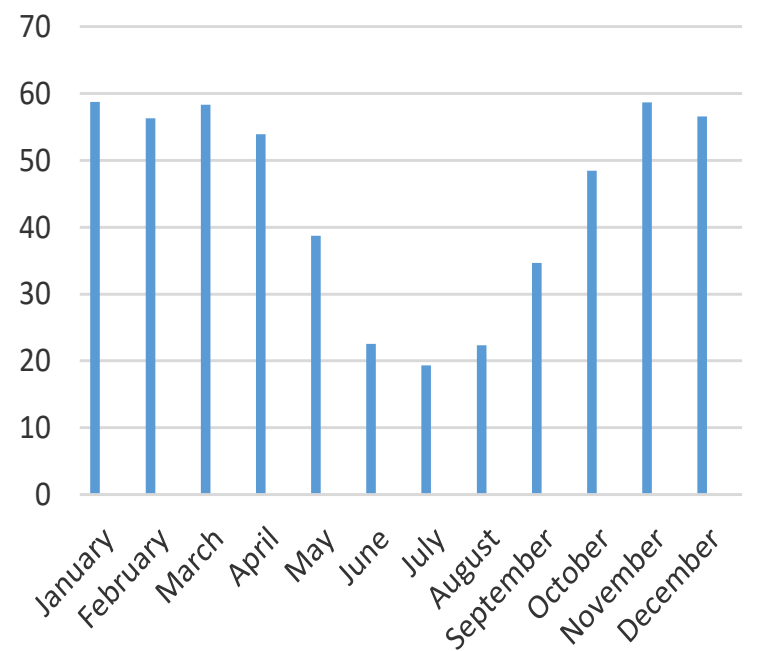

Fig. 17. Monthly Power Generation in GW-hr

Analysis of the data presented in figure (18-22) allows us to calculate the efficiency of each of the subsections and also the power plant as a whole using the previously mentioned equations. The results are shown in table-7.

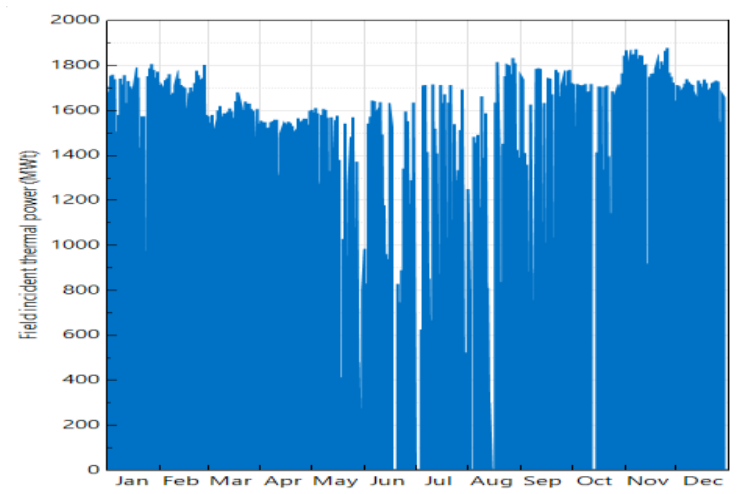

Fig. 18. Annual Solar Power Incident on the Field (MWt) 


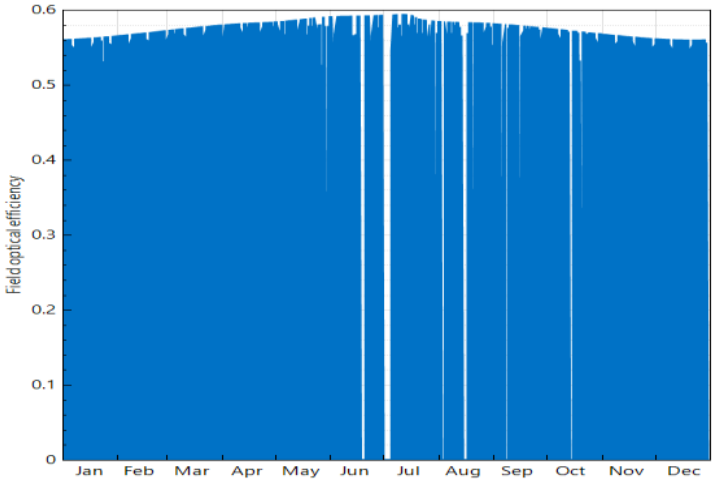

Fig. 19. Optical Efficiency of the Field

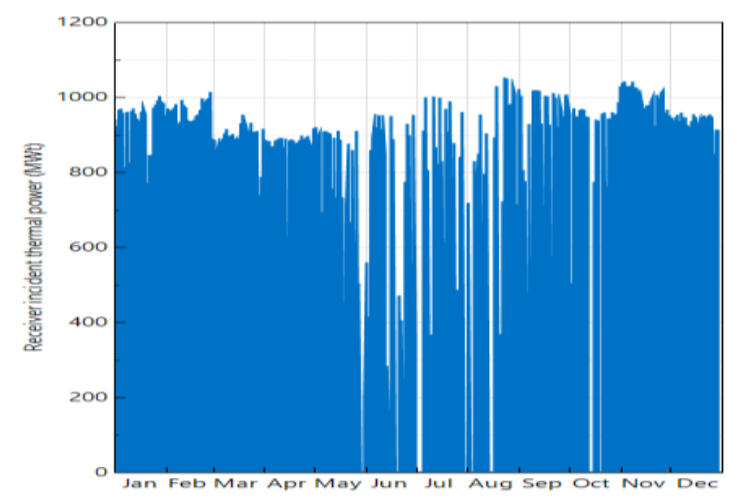

Fig. 20. Receiver Thermal Power Incident (MWt)

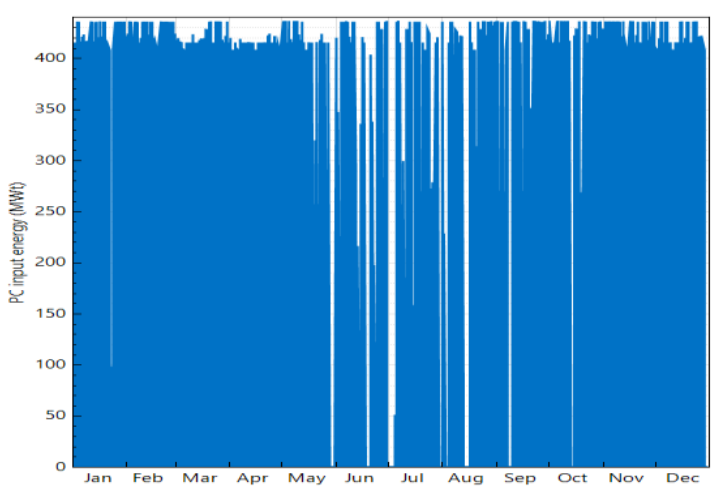

Fig. 21. Power Cycle Input Energy

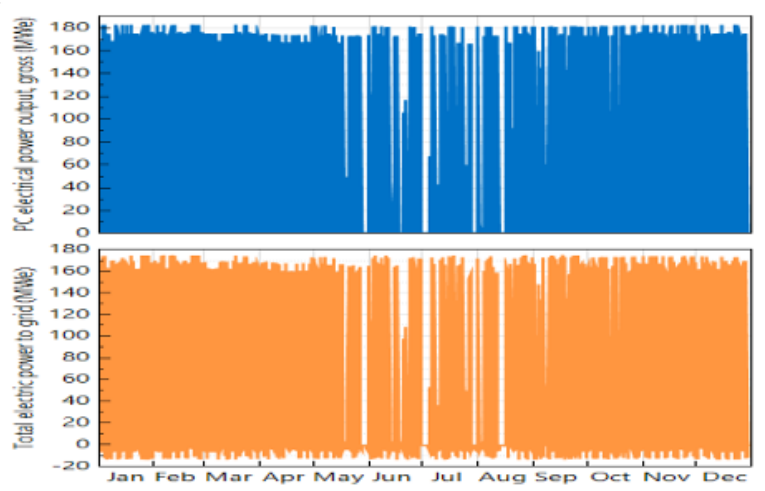

Fig. 22. Power Cycle Gross and Net Power Output

Table. 7. Efficiency of Different Sub-Sections

\begin{tabular}{|l|l|}
\hline Efficiency of Solar Field & $49 \%$ \\
\hline Efficiency of Receiver & $92.27 \%$ \\
\hline Power Cycle Efficiency & $38.8 \%$ \\
\hline Gross Efficiency of the & $17.52 \%$ \\
\hline
\end{tabular}

\begin{tabular}{|l|l|}
\hline Power Plant & \\
\hline $\begin{array}{l}\text { Gross-Net Conversion } \\
\text { Efficiency }\end{array}$ & $88.635 \%$ \\
\hline
\end{tabular}

Finally, the performance of the power plant designed in this study was compared with some running solar tower based thermal power plants all around the world including in countries like Israel, Spain and South Africa and the comparison outcomes are shown in table- 8 . From the table it is evident that, the power plant is performing up to the mark and is possible to be implemented technically in Bangladesh.

Table. 8. Performance Comparison with Running Solar Tower Power Plants Around the World.

\begin{tabular}{|l|l|l|l|}
\hline $\begin{array}{l}\text { Name of } \\
\text { Project }\end{array}$ & Location & $\begin{array}{l}\text { Maximum } \\
\text { Rated } \\
\text { Power } \\
\text { (MW) }\end{array}$ & $\begin{array}{l}\text { Annual } \\
\text { Power } \\
\text { Production } \\
\text { (GWh-e) }\end{array}$ \\
\hline This Work & Bangladesh & 150 & 528.66 \\
\hline $\begin{array}{l}\text { Ashalim } \\
\text { Power } \\
\text { Station }\end{array}$ & Israel & 121 & 320 \\
\hline $\begin{array}{l}\text { PS20 Solar } \\
\text { Power } \\
\text { Tower }\end{array}$ & Spain & 20 & 44 \\
\hline $\begin{array}{l}\text { Khi Solar } \\
\text { One }\end{array}$ & $\begin{array}{l}\text { South } \\
\text { Africa }\end{array}$ & 50 & 180 \\
\hline
\end{tabular}

\section{Conclusion}

In this study several key design parameters of solar tower thermal power plant were studied along with determining the most suitable location for exploiting solar energy using CSP technology in Bangladesh based on GHI and DNI data. An attempt was taken to optimize the heliostat field based on the key design points such as design point DNI, solar multiple and design point temperature. Effect of these design points on the overall design and performance of the plant were analyzed and optimization was done accordingly by simulating a 150 MW solar tower thermal power plant.

Sizing and optimizing the heliostat field is the most crucial and tiresome part of designing a solar tower power plant and in this study, it was done for Bangladesh using various methods which can effectively be used in places with similar climatic conditions all over the world. Simulation results of the designed and optimized power plant using SAM software revealed that the performance was up to the mark and comparing it with other operating solar tower thermal power plants all over the world showed that it is technically feasible to be implemented in Bangladesh. Moreover, the power plant designed in this paper can be used as a blueprint to design an actual solar tower plant in Bangladesh which would obviously be a remarkable landmark for Bangladesh in the renewable energy sector. However, further study and sensitivity analysis can bring out more ways to make the power plant more efficient and also a thorough economic analysis can be carried out to judge 
the economic feasibility of such projects. Similar studies can also be carried out for other CSP technologies like PTC, LFR or Dish Stirling.

\section{References}

1. N. Mohammad and Y. Mishra, "Transactive market clearing model with coordinated integration of large-scale solar PV farms and demand response capable loads," 2017 Australas. Univ. Power Eng. Conf. AUPEC 2017, vol. 2017-Novem, pp. 1-6, 2018.

2. M. Quamruzzaman, N. Mohammad, M. A. Matin, and M. R. Alam, "Highly efficient maximum power point tracking using DC-DC coupled inductor single-ended primary inductance converter for photovoltaic power systems, ” Int. J. Sustain. Energy, vol. 35, no. 9, pp. 914-932, 2016.

3. C. Xu, Z. Wang, X. Li, and F. Sun, "Energy and exergy analysis of solar power tower plants, ” Appl. Therm. Eng., vol. 31, no. 17-18, pp. 3904-3913, 2011.

4. S. Hossain, S. Shajid, "Design Optimization , Simulation \& Performance Analysis of 100MW Solar Tower Thermal Power, ” pp. 323-330, 2020.

5. [5] I. M. Faisal and S. Parveen, "Food security in the face of climate change, population growth, and resource constraints: Implications for Bangladesh," Environmental Management, vol. 34, no. 4. pp. 487-498, 2004.

6. S. Islam and M. Z. R. Khan, "A Review of Energy Sector of Bangladesh,” Energy Procedia, vol. 110, no. December 2016, pp. 611-618, 2017.

7. N. Mohammad and Y. Mishra, "The role of demand response aggregators and the effect of GENCOS strategic bidding on the flexibility of demand," Energies, vol. 11, no. 12, 2018.

8. N. Mohammad and Y. Mishra, "Coordination of wind generation and demand response to minimise operation cost in dayahead electricity markets using bi-level optimisation framework," IET Gener. Transm. Distrib., vol. 12, no. 16, pp. 3793-3802, 2018.

9. Power Division, "Power System Master Plan 2016., ” Minist. Power, Energy Miner. Resour. Gov. People's Repub. Bangladesh, no. September, pp. 1137, 2016.

10. A. Barua, S. Chakraborti, D. Paul, and P. Das, "Analysis of Concentrated Solar Power Technologies' Feasibility, Selection and Promotional Strategy for Bangladesh," J. Mech. Eng., vol. 44, no. 2, pp. 112-116, 2015.

11. S. Nabeel, "Energy consumptions and PV system cost comparison between energy audited and nonenergy audited facility ., " pp. 187-190, 2017.

12. P. Of, S. Power, and I. T. S. Applications, “ICMERE2015-PI-074," vol. 2015, pp. 26-29, 2015.

13. K. Anam and Husnain-Al-Bustam, "Power Crisis \& Its Solution through Renewable Energy in
Bangladesh,” J. Sel. Areas Renew. Sustain. Energy, pp. 13-18, 2011.

14. S. H. Khan, T. Rahman, and S. Hossain, "Prospect of Solar Energy in Generation of Electricity in Bangladesh," Multidiscip. Journals Sci. Technol. J. Sel. Areas Renew. Sustain. Energy, vol. June Editi, no. September 2012, p. 8, 2013.

15. M. P. Taufiq Rohman, S.Pd.I, "An Overview of Concentrated Solar Power (CSP) Technologies and its Opportunities in Bangladesh," Psikol. Perkemb., no. October 2013, pp. 1-224, 2019.

16. Z. Yao, Z. Wang, Z. Lu, and X. Wei, “Modeling and simulation of the pioneer $1 \mathrm{MW}$ solar thermal central receiver system in China," Renew. Energy, vol. 34, no. 11, pp. 2437-2446, 2009.

17. X. Li, W. Kong, Z. Wang, C. Chang, and F. Bai, "Thermal model and thermodynamic performance of molten salt cavity receiver," Renew. Energy, vol. 35, no. 5, pp. 981-988, 2010.

18. L. Jianfeng, D. Jing, and Y. Jianping, "Heat transfer performance and exergetic optimization for solar receiver pipe," Renew. Energy, vol. 35, no. 7, pp. 1477-1483, 2010.

19. R. Chen, Z. Rao, and S. Liao, "Determination of key parameters for sizing the heliostat field and thermal energy storage in solar tower power plants," Energy Convers. Manag., vol. 177, no. May, pp. 385-394, 2018

20. A. B. Zavoico, “Solar Power Tower - Design Basis Document,” Tech. Rep. SAND2001-2100, no. July, p. 148, 2001.

21. A. M. Kruizenga, D. D. Gill, and M. Laford, "Materials Corrosion of High Temperature Alloys Immersed in $600{ }^{\circ}$ C Binary Nitrate Salt," Sandia Rep., vol. SAND 2013-, no. March, pp. 1-57, 2013

22. M. N. S. K. Shabbir, M. S. A. Chowdhury, and X. Liang, "A guideline of feasibility analysis and design for concentrated solar power plants," Can. J. Electr. Comput. Eng., vol. 41, no. 4, pp. 203-217, 2018.

23. NREL. (2018). SAM Webinars 2017: Modeling Molten Salt Power Tower Systems in SAM 2017.1.17.

24. S. Sukumaran and K. Sudhakar, "Fully solar powered Raja Bhoj International Airport: A feasibility study,” Resour. Technol., vol. 3, no. 3, pp. 309-316, 2017

25. A. Sahu, N. Yadav, and K. Sudhakar, "Floating photovoltaic power plant: A review," Renew. Sustain. Energy Rev., vol. 66, pp. 815-824, 2016

26. B. Shiva Kumar and K. Sudhakar, "Performance evaluation of $10 \mathrm{MW}$ grid connected solar photovoltaic power plant in India," Energy Reports, vol. 1, pp. 184-192, 2015 